Marwah M Shehab BDS, MSc (Asst. Lec.)

\section{Effect of Microwave Disinfection on Hardness of Acrylic Base Denture Lin- ing Material}

Dept of Prosthodontic Dentistry College of Dentistry, University of Mosul

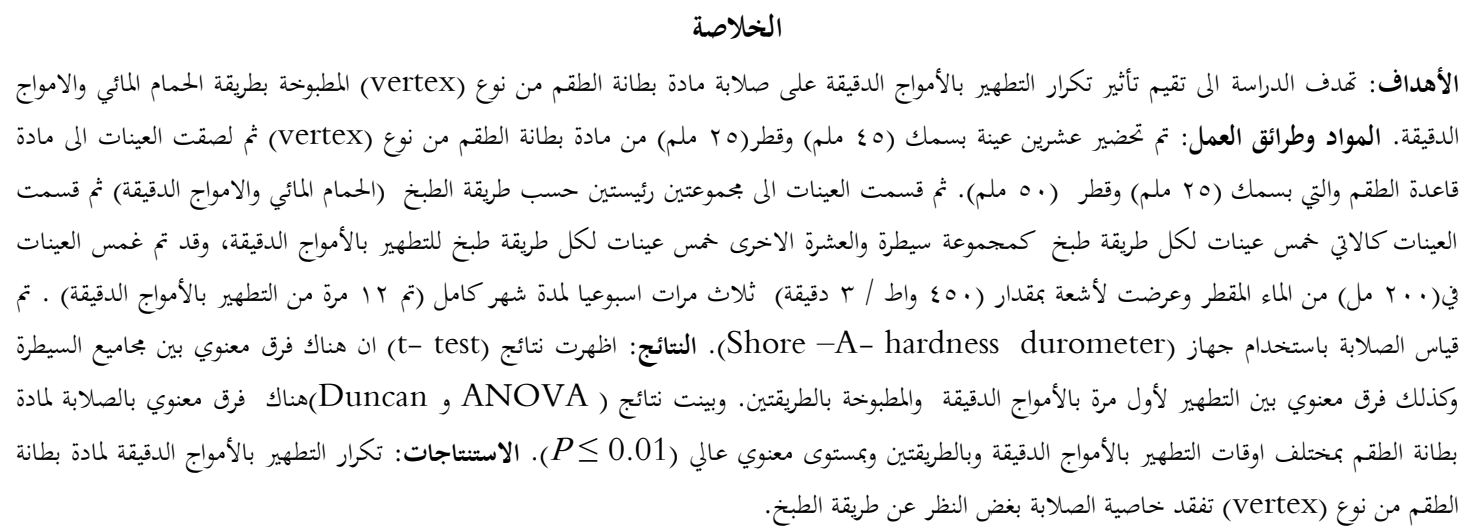

\title{
ABSTRACT
}

Aims: To evaluated the effect of the repeated microwave disinfection on hardness of vertex denture lining material cured by water bath and microwave. Materials and Methods: Twenty specimens were prepared $4.5 \mathrm{~mm}$ thickness $\times 25 \mathrm{~mm}$ in diameter from denture lining material (Vertex, Holland) adhered to specimen $2.5 \mathrm{~mm}$ thickness $\times 50 \mathrm{~mm}$ in diameter form a heat-cured acrylic resin (Vertex, Holland) and divided into two main groups according to the curing method (waterbath and microwave). The specimens were divided as following, ten specimens, five for each curing method as a control group. The other ten, five specimens for each curing method for microwave disinfection, specimens immersed in $200 \mathrm{ml}$ of distilled water and irradiated with 540 Watt per 3 minute, three times weekly for one month started from the first time of microwave irradiation (microwave disinfection) to twelve times, tested for hardness by using Shore -A- hardness durometer. Results: The independent t-test revealed that, significant differences between control groups (specimens cured by water bath higher than that cured by microwave method), and significant differences between first time of disinfection by domestic microwave oven cured by two methods. The analysis of variance (ANOVA) and Duncan multiple range test confirmed there is a significant difference in hardness of denture lining material in different times of disinfection by domestic microwave oven for both curing methods at significant level $(P \leq 0.01)$. Conclusion: The repeated disinfection by microwave irradiation deteriorated the vertex denture lining material regardless to the curing methods.

Key words: denture lining material, microwave disinfection

Shehab MM. Effect of Microwave Disinfection on Hardness of Acrylic Base Denture Lining Material. Al-Rafidain Dent J. 2013; 13(1): 128-135 .

Received: 14/9/2011 Sent to Referees: 19/9/2011 Accepted for Publication: 13/12/2011

\section{INTRODUCTION}

A denture may require relining of the intaglio surface as a result of tissue changes overtime. $^{(1)}$ Soft lining materials are widely used as a cushion on the fitting surface of dentures in the management of traumatized oral mucosa, bony undercuts, bruxism, ridge atrophy, and for congenital oral defects requiring obturation. ${ }^{(2-4)}$ Where the denture-bearing tissues are less able to withstand masticatory stresses, soft denture liners provide an even distribution of the functional load on the denture-bearing area and avoid local stress concentrations. ${ }^{(5,6)}$

Acrylic resin-based resilient liner materials generally consist of polymers and monomers. The composition of the polymers and monomers is proprietary, but these materials generally include methacrylate polymers and copolymers, along with a liquid containing methacrylate monomer and plasticizers (ethyl alcohol and/or phthalate). ${ }^{(7)}$ 
The polymerization of denture base resin by microwave energy has been studied for more than three decades. The advantages of polymerizing denture base resin by microwave energy greatly reduced polymerization time, a cleaner method of processing, and a denture base with superior adaptation to the dental cast. ${ }^{(8,9)}$ The clinical properties of resilient denture liners may be influenced by method of which they are polymerized. ${ }^{(10)}$

The dentures may become contaminated with microorganisms, ${ }^{(11)}$ and crosscontamination of the prostheses may occur when the infected units are pumiced in dental laboratories. ${ }^{(12)}$ Therefore, denture disinfection has been recommended to avoid cross contamination and prevent denture-related stomatitis. ${ }^{(11,13)}$ The selection of a disinfection method should be based not only on its effectiveness against microorganisms, but also on its effects on the denture materials. ${ }^{(6)}$ Microwave irradiation has been suggested as a method to disinfect denture bases ${ }^{(14)}$ Placing contaminated denture materials in water during microwave exposure is required to kill rather than inhibit yeast growth. ${ }^{(13,15,16)}$

\section{MATERIALS AND METHODS}

Twenty specimens were prepared form a heat-cured acrylic resin (Vertex, Holland) which divided into two main groups according to curing methods (water bath and microwave). The sample was prepared by disc of wax of $4.5 \mathrm{~mm}$ thickness and $25 \mathrm{~mm}$ in diameter adhered to a disc of Biostar material of $2.5 \mathrm{~mm}$ thickness and $50 \mathrm{~mm}$ in diameter by a using hot wax knife was put on a stone mould inside a metal flask. ${ }^{(17)}$ The heat cured acrylic denture base material wax mixed according to the manufacturer instructions until it reached the dough stage, then the metal flask was opened and the Biostar disc was removed leaving the wax disc in it's place. The dough was packed in the stone mold instead of Biostar disc and a layer of selovent was applied between the acrylic and the wax, and the metal flask was closed, pressed under a hydraulic press according to the manufacturer instructions. After that the flask was re-opened, remove the piece of wax and the selovent layer. The denture lining material (vertex, Holland) was mixed according to the manufacturer instructions and put it in the stone mould instead of wax, then the flask was reclosed and pressed under a hydraulic press for fifteen minutes. The specimens of the first group were cured by water bath (according to its manufacturer instruction) and the specimens of the second group were cured by domestic microwave oven (LG, Korea) at 90 Watt for 13 minutes +500 watt for 90 seconds ${ }^{(18)}$ by using fiberglass flask. The flash was trimmed with a scalpel. The specimens divided as following:- ten specimens, five for each curing method as a control groups. Another ten specimens, five for each curing method for microwave disinfection, specimens were immersed in 200 $\mathrm{ml}$ of distilled water ${ }^{(16)}$ and irradiated with 540 Watt per 3 minute $^{(19)}$ three times weekly for one month ${ }^{(20)}$ started form the first time of microwave irradiation (microwave disinfection) to twelve times, the specimens left on bench cooling then tested for hardness by using Shore -A- hardness durometer, The specimens stored in water at $37^{\circ} \mathrm{C}$ between exposure after each irradiation by microwave. The measurement was based on the penetration of an indentor into a specimen. Shore $-\mathrm{A}-\mathrm{du}-$ rometer contain a scale reading from 30 to 100 shore $-\mathrm{A}$ - hardness units, Shore $-\mathrm{A}$ durometer having tapered tip diameter $1 / 16$ inch base and $1 / 32$ inch at tip.

The specimens were placed on a bench, the shore-A- durometer (Figure 1), was held in a vertical position with the point of the indentor $5 \mathrm{~mm}$ from the periphery of the specimen. The tip of the indentor was applied perpendicularly to the surface of the specimen, care was taken to ensure that the long axis of the indentor was perpendicular to the surface of the specimen in order to ensure accurate reading. Sufficient pressure was applied as rapidly as possible in order to obtain firm contact between the foot of the insetrument and the smooth surface of the specimen. Readings were taken after 1 second from the firm contact was achieved between the dureometer foot and the material under test. ${ }^{(21)}$ Three measurements were recorded for each specimen at a time and the mean was calculated by using SPSS statically analysis version (11.5). 


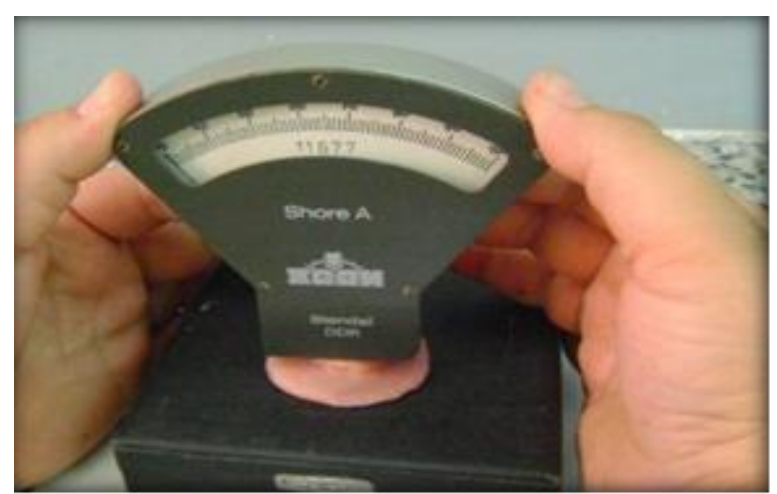

\section{RESULTS}

Table (1) demonstrated the descriptive statistic and independent $\mathrm{T}$ - test of hardness for denture lining material (DLM) cured by both methods (waterbath and microwave), revealed that there are significant differences between control groups (specimens cured by water bath higher than that cured by microwave method), and significant differences be-
Figure (1): Testing procedure of Hardness Durometer

Table (1): Descriptive Statistic and t- test of Hardness for Denture Lining Material Cured by Water Bath and Microwave After Repeated Disinfections by Microwave.

\begin{tabular}{|c|c|c|c|c|c|c|c|c|c|}
\hline Duration & Methods & No. & Minimum & Maximum & Mean & Std. Dev & DF & T-test & $P$-Value \\
\hline \multirow[t]{2}{*}{ control } & WB & 5 & 35 & 38 & 36.88 & 0.509 & 8 & 2.649 & $0.029 *$ \\
\hline & MW & 5 & 35 & 36.5 & 35.32 & 0.661 & & & \\
\hline \multirow[t]{2}{*}{ First } & WB & 5 & 40.5 & 42 & 41.3 & 0.670 & 8 & -2.708 & $0.027 *$ \\
\hline & MW & 5 & 41.6 & 44 & 42.76 & 1.001 & & & \\
\hline \multirow[t]{2}{*}{ Second } & WB & 5 & 43.2 & 44.6 & 43.88 & 0.521 & 8 & 1.253 & 0.245 \\
\hline & MW & 5 & 42 & 45 & 43.2 & 1.095 & & & \\
\hline \multirow[t]{2}{*}{ Third } & WB & 5 & 43 & 48 & 45.326 & 1.875 & 8 & 0.302 & 0.77 \\
\hline & MW & 5 & 43 & 48 & 44.966 & 1.894 & & & \\
\hline \multirow[t]{2}{*}{ Forth } & WB & 5 & 47 & 52 & 49.733 & 1.935 & 8 & 1.752 & 0.118 \\
\hline & MW & 5 & 45.33 & 49 & 47.831 & 1.463 & & & \\
\hline \multirow[t]{2}{*}{ Fifth } & WB & 5 & 50.333 & 53 & 51.499 & 1.178 & 8 & -1.741 & 0.120 \\
\hline & MW & 5 & 51 & 54 & 52.75 & 1.089 & & & \\
\hline \multirow{2}{*}{ Sixth } & WB & 5 & 53 & 56 & 54.7 & 1.095 & 8 & -0.926 & 0.381 \\
\hline & MW & 5 & 54.25 & 56 & 55.25 & 0.750 & & & \\
\hline \multirow[t]{2}{*}{ Seventh } & WB & 5 & 50 & 61 & 57.7 & 4.41 & 8 & -0.377 & 0.716 \\
\hline & MW & 5 & 57 & 60 & 58.466 & 1.120 & & & \\
\hline \multirow[t]{2}{*}{ Eighth } & WB & 5 & 58 & 61 & 59.4 & 1.341 & 8 & -0.254 & 0.806 \\
\hline & MW & 5 & 58 & 61 & 59.6 & 1.140 & & & \\
\hline \multirow[t]{2}{*}{ Ninth } & WB & 5 & 60 & 64.5 & 61.9 & 2.79 & 8 & -0.351 & 0.735 \\
\hline & MW & 5 & 61 & 64 & 62.3 & 1.303 & & & \\
\hline \multirow[t]{2}{*}{ Tenth } & WB & 5 & 62 & 65 & 63.4 & 1.341 & 8 & -0.221 & 0.831 \\
\hline & MW & 5 & 62 & 65 & 63.6 & 1.516 & & & \\
\hline \multirow[t]{2}{*}{ Eleventh } & WB & 5 & 64.5 & 67 & 65.5 & 1.00 & 8 & -0.475 & 0.648 \\
\hline & MW & 5 & 64 & 68 & 65.9 & 1.596 & & & \\
\hline \multirow[t]{2}{*}{ Twelfth } & WB & 5 & 66 & 68 & 66.8 & 0.836 & 8 & -0.310 & 0.764 \\
\hline & MW & 5 & 65.5 & 68 & 67 & 1.172 & & & \\
\hline
\end{tabular}

WB: Waterbath, MW: Microwave, No.: Number, Std-Dev.: Stander Deviation, DF: Degree of Freedom, *significant difference at $P \leq 0.01$.

tween first time of disinfection by microwave cured by two methods. The analysis of variance (one way ANOVA), is illustrated in table (2), and confirmed there is a significant difference in hardness of denture lining material in different times of disinfection by domestic microwave oven for both curing methods at significant level $(P \leq 0.01)$. 
Table (2): Analysis of Variance (ANOVA) of Hardness for Denture Lining Materials Cured byWaterbath and Microwave Curing Methods

\begin{tabular}{lllllll}
\hline Methods & & Sum of Squares & DF & Mean Squares & F & $P$-Value \\
\hline Waterbath & Between Groups & 5774.771 & 12 & 481.231 & 151.029 & $0.000^{*}$ \\
& Within Groups & 165.691 & 52 & 3.186 & & \\
& Total & 5940.462 & 64 & & & \\
Microwave & Between Groups & 6145.618 & 12 & 512.135 & 324.043 & $0.000^{*}$ \\
& Within Groups & 82.183 & 52 & 1.580 & & \\
& Total & 6227.801 & 64 & & & \\
\hline
\end{tabular}

DF: Degree of Freedom, *significant difference at $P \leq 0.01$.

Figure $(2,3)$ Duncan multiple range test revealed that there are significant difference between control and all others groups disinfectant by microwave oven for both curing methods, the twelve times of disinfection by microwave show higher effected on denture lining material for both curing methods.

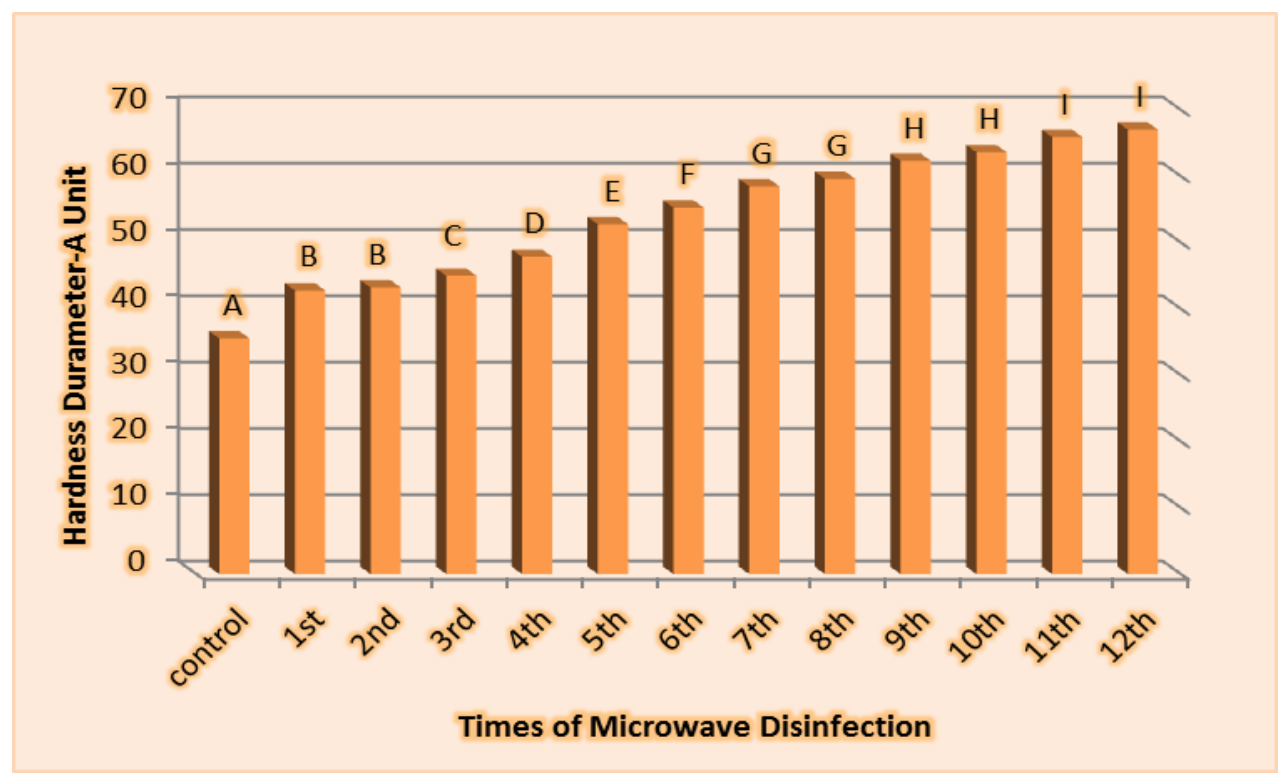

Figure (2): Duncan Multiple Range Test of Hardness of Vertex Denture Lining Material Cured by Microwave Oven After Times of Microwave Disinfection 


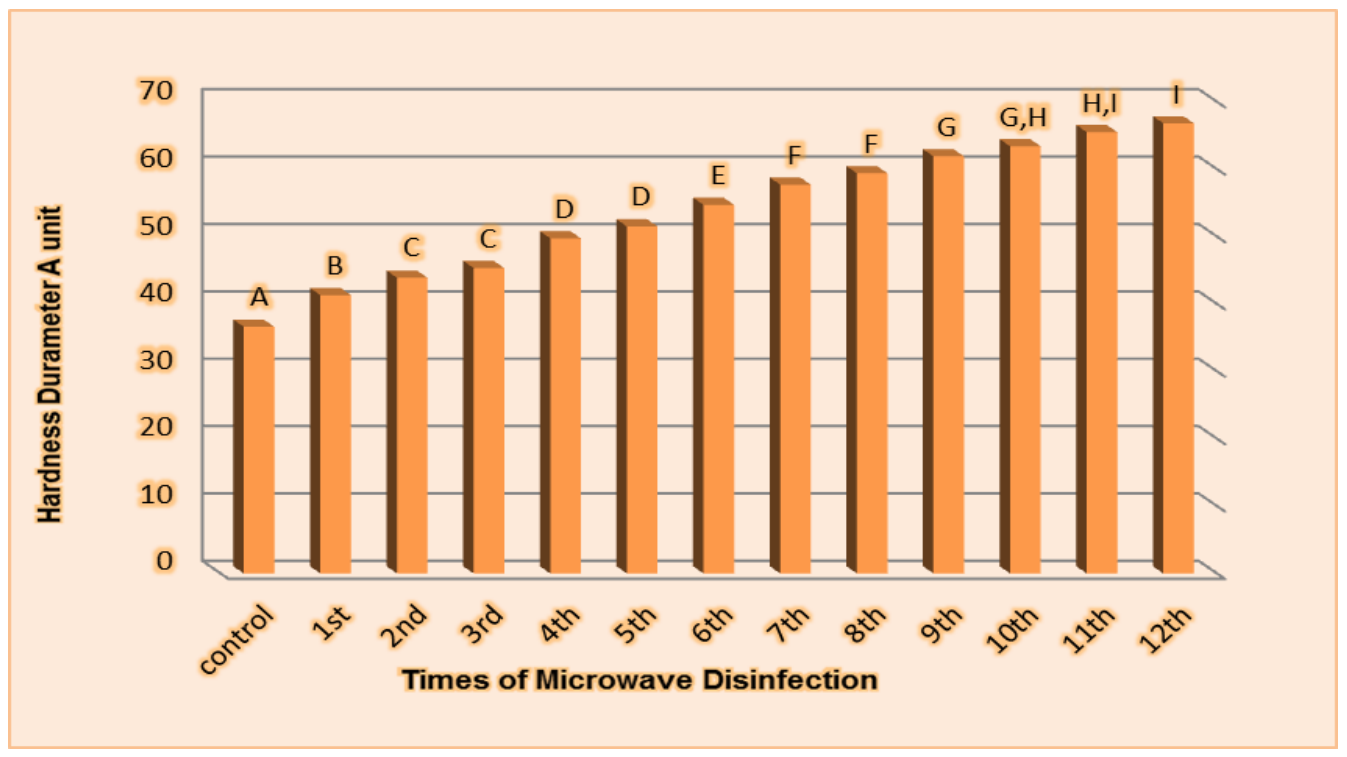

Figure (3): Duncan Multiple Range Test of Hardness of Vertex Denture Lining Material Cured by Waterbath After Times of Microwave Disinfection

\section{DISCUSSION}

From Table (1) t- test reveled there are significant differences between control groups(specimens cured by water bath higher than that cured by microwave method), and significant difference between the first time of disinfection by microwave cured by two methods. The polymerization method of soft lining materials may influence their physical properties. ${ }^{(22)}$ According to some authors, ${ }^{(23-25)}$ materials processed in the laboratory using conventional laboratory techniques may exhibit a higher degree of polymerization than materials not submitted to elevated temperatures and pressures, suggesting that these materials present better physical/mechanical properties. ${ }^{(26)}$ The conversion of polymer using the microwave method (highly temperature reached during microwave irradiation) resulted in high level of residual monomer than in conventional water bath technique. ${ }^{(27)}$ The hardness of denture lining material has been shown to be proportional to the residual monomer (act as aplastizier), ${ }^{(28)}$ Microwave curing at low wattage for 30 minutes with an additional 1.5 minute at high wattage, rather than shorter times at higher wattage, increased the level of monomer conversion and produced a low level of residual monomer. ${ }^{(29)}$ In this study using (90Watt for 13minutes) and (500 Watt for 1.5 minutes) may result in higher residual monomer content compared to the water bath curing method in which a 30 minutes terminal boil was used which result in higher residual monomer conversion. The magnitude of the effect is the of composition and degree of conversion of the material.

It is difficult to relate the findings of the present study to other investigations, because of the differences in specimen shape, dimension, type of denture base acrylic resin and resilient lining materials, and processing technique. From tables $(1,2)$ and figure $(2,3)$ reveled there are significant differences for both waterbath and microwave curing methods after repeated microwave disinfection, this agree with Machado et al, ${ }^{(30)}$ they concluded that Microwave disinfection and immersion in distal water at $37^{\circ} \mathrm{C}$ for 30 days resulted in a small but significant increase in hardness of soft lining material, but disagree with Dixon $e t a l,{ }^{(13)}$ evaluated the effect of 5 exposures to microwave irradiation as a disinfection method for dentures on the hardness of denture base and relining materials, the authors found that there are no significant differences for the resilient lining material and the denture base acrylic resin.

A significant increase in hardness was observed when the specimens were disinfected using microwave irradiation. One possible explanation is the temperature of 
water in which the specimens were immersed during disinfection was increased by microwave irradiation. ${ }^{(15)}$ When the specimens were heated the water started to boil after approximately 90 seconds of microwave disinfection. It is likely that the higher temperature of water may increase mobility of residual monomer molecules in the polymer matrix and the may lead to a further polymerization reaction ${ }^{(31)}$ this will enhance the diffusion of remaining residual monomer molecules out of the resin, therefore, the increase in hardness observed in present investigation could be related to a decrease in residual monomer level as a result of further polymerization. ${ }^{(14,15)}$ All specimens immersed in distal water during microwave irradiation, this can be assumed that the residual monomer that may have leached from the specimens during microwave irradiation lead to increased hardness. ${ }^{(32)}$ The initial softness was due to the quantity of plasticizer and the residual monomer act as plasticizer in the material, since plasticizers are responsible for maintaining the softness of the acrylic resin based resilient liner materials. Leaching of plasticizers causes hardening of the acrylic resin based resilient liners. ${ }^{(3)}$

Release of plasticizers and other byproducts of the polymerization reaction from resilient liners ${ }^{(34,35)}$ has been suggested as the one reason for hardness changes. The hardness of the resilient lining materials increased after thermal cycling, which hardens the specimen and works against the effect of water uptake that would normally causes softening. ${ }^{(5)}$

Even though, the optimal hardness values of soft denture liners for clinical use have not been determined, ${ }^{(36)}$ their shock-absorbing properties are known to increase with their softness, thus lower hardness is a desirable property for soft denture liners. ${ }^{(8)}$ The maintenance of this property is a major problem during use of soft liners, since some of these materials are not stable in an aqueous environment, such as the oral cavity, and/or when immersed in disinfection solutions. ${ }^{(7,37)}$

\section{CONCLUSION}

The repeated disinfection by microwave irradiation for vertex denture lining material cured by (waterbath and microwave oven) significantly affect the hardness and deteriorated the vertex denture lining material regardless to the curing methods.

\section{REFERENCES}

1. Arima T, Murata H, Hamada T. Analysis of composition and structure of hard autopolymerizing reline resins. $J$ Oral Rehabil 1996; 23: 346-352

2. Craig RG and Power JM. Prosthetic Application of Polymer. Restorative Dental Materials. 11th ed. St Louis: CV mosby. 2002; P: 635-682.

3. Pereira- Cence T. Development of candida-associated denture stomatitis: new insights. J Appl Oral Sci. 2008;16(2): 86-94.

4. Park SK, Lee YK, Lim BS and Kim $\mathrm{CW}$. Changes in properties of shortterm- use soft liners after thermocycling. J Oral Rehabil. 2004; 31(7): 717-724.

5. Baysan A, Parker S, and Wright PS. Adhesion and tear energy of a longterm soft lining material activated by rapid microwave energy. J Prosthet Dent. 1998;79: 182-87.

6. Machado AL, Breeding LC, and Puckett AD. Effect of microwave disinfection procedures on torsional bond strengths of two hard chairside denture reline materials. J Prosthodont. 2006; 15: 337-344.

7. Gronet PM, Driscoll CF, and Hondrum SO. Resiliency of surface-sealed temporary soft denture liners. $J$ Prosthet Dent.1997;77: 370-4.

8. Levin B, Sanders JL, and Reitz PV. The use of microwave energy for processing acrylic resins. J Prosthet Dent. 1989; 61:381-383.

9. Pero AC, Barbosa DB, Marra J, Ruvolo-Filho AC, and Compagnoni MA. Influence of microwave polymerization method and thickness on porosity of acrylic resin. J Prosthodont. 2008; 17: 125-129.

10. Parr GR, Rueggeberg FA. In vitro hardness, water sorption, and resin solubility of laboratory processed and autopolymerized long-term resilient denture liners over one year of water storage. J Prosthet Dent. 2002; 88:139-44. 
11. Pavarina AC, Pizzolitto AC, and Machado AL. An infection control protocol: effectiveness of immersion solutions to reduce the microbial growth on dental prostheses. $J$ Oral Rehabil. 2003; 30: 532-536.

12. Witt S,Hart P. Cross-infection hazards associated with the use of pumice in dental laboratories. J Dent. 1990; 18: 281- 283.

13. Dixon DL, Breeding LC, and Faler TA. Microwave disinfection of denture base materials colonized with Candida albicans. J Prosthet Dent. 1999; 81: 207-214

14. Seo RS, Vergani CE, Pavarina AC, Compagnoni MA, and Machado AL. Influence of microwave disinfection on the dimensional stability of intact and relined acrylic resin denture bases. $J$ Prosthet Dent. 2007; 98: 216-223.

15. Neppelenbroek KH, Pavarina AC, Spolidorio DM, Vergani CE, Mima EG, Machado AL. Effectiveness of microwave sterilization on three hard chairside reline resins. Int $J$ Prosthodont. 2003;16: 616-20.

16. Mustafa EA, Jawad IA, and Abd Alkadder AA. Effectiveness of microwave sterilization on soft lining material. Al-Rafidain Dent J. 2010; 10(1): 133-142.

17.Kazaniji MN and Watkinson AC. Soft lining materials:their absorption of and solubility in artificial saliva. $\mathrm{Br}$ Dent $J$. 1988; 165: 91-94.

18.Bonatti MR, CunhaTR, RegisRR, Silva-Lovato $\mathrm{CH}$, Paranhos HFO, and Souza RF. The effect of polymerization cycles on color stability of microwaveprocessed denture base resin. J Prosthodont. 2009; 18: 432-437.

19.Al-Saraj ANM. Evaluation of microwave disinfection and its effect on some physical properties of acrylic resin denture base materials. 2008, M. Sc. Thesis, university of Mosul.

20.Neppelenbroek KH, Pavarina AC, Palomarispolidorio DM, Sgavioli massucato EM, LC Spolidorio and CE Vergani. Effectiveness of microwave disinfection of complete dentures on the treatment of Candida-related denture stomatitis. J Oral Rehabil. 2008; 35: 836-846.
21.Al-neema HSS. Evaluation of propolis to modify soft denture lining materials.2011, M. Sc. Thesis, university of Mosul.

22. Qudah S, Harrison A, Huggett R: Soft lining materials in prosthetic dentistry: a review. Int J Prosthodont 1990; 3: 477-483

23. Craig RG and Gibbons P. Properties of resilient denture liners. J Am Dent Assoc. 1961; 63: 382-390.

24. Polyzois GL, Zissis AJ, Yannikakis SA. The effect of glutaraldehyde and microwave disinfection on some properties of acrylic denture resin. Int $J$ Prosthodont. 1995; 8:150-154.

25. Parr GR and Rueggeberg FA. In vitro hardness, water sorption, and resin solubility of laboratory-processed and autopolymerized long-term resilient denture liners over one year of water storage. J Prosthet Dent. 2002; 88:139144.

26.Pavan S, Filho J, Santos P, Nogueira $S^{\prime}$, and Batista A. Effect of disinfection treatments on the hardness of soft denture liner materials. $J$ Prosthodont. 2007; 20: 101-106.

27.Al- Doori D, Huggett R, Bates J, Brooks S. A comparison of denture base acrylic resins polymerised by microwave irradiation and by conventional water bath curing systems. Dent $M a$ ter. 1988; 4:25-32.

28.Arab J, Newton JP, and Lloyd CH. The effect of an elevated level of residual monomer on the whitening of denture base and its physical properties. $J$ Dent. 1989; 17: 189-194.

29. Al-Azzawi SI. Evaluation of some physical and mechanical properties of acrylic denture base material cured by two different type of microwave irradiation. M.Sc thesis, College of Dentistry, University of Baghdad. 1998.

30. Machado AL, Breeding LC, and Puckett AD. Effect of microwave disinfection on the hardness and adhesion of two resilient liners. $J$ Prosthet Dent. 2005; 94:183-9.

31.Dootz ER, Koran A, Craig RG.Comparison of the physical properties of 11 soft denture liners. $J$ Prosthet Dent.1992; 67: 707-12.

32.Machado AL, Breeding LC, Vergani 
$\mathrm{CE}$, and Perez LE. Hardness and surface roughness of reline and denture base acrylic resins after repeated disinfection procedures. J Prosthet Dent. 2009; 102: 115-122.

33. Glass RT, Bullard JW, Hadley CS, Mix EW, Conrad RS. Partial spectrum of microorganisms found in dentures and possible disease implications. J Am Osteopath Assoc 2001; 101: 92-4.

34. Murata H, Kawamura M, Hamada T, Saleh S, Kresnoadi U, Toki K. Dimensional stability and weight changes of tissue conditioners. J Oral Rehabil. 2001; 28: 918-23.
35. Crawford CA, Lloyd CH, Newton JP, Yemm R. Denture bleaching: a laboratory simulation of patients' cleaning procedures. J Dent 1986;14:258-61.

36.Tan H, Woo A, and Kim S. Effect of denture cleansers, surface finish, and temperature on Molloplast B resilient liner color, hardness and texture. $J$ Prosthodont. 2000; 9: 148-155.

37. Canay S, Hersek $\mathrm{N}$ and Tulunoglu I. Evaluation of color and hardness changes of soft lining materials in food colorant solutions. J Oral Rehabil. 1999; 26: 821-829. 